\title{
Role of Ethanolic Extract of Microdus brasiliensis (Duby) Ther. in Protecting Survival Rate in Sepsis: An In vivo Study
}

\begin{abstract}
K. N. KILLARI*, HO VIET HIEU ${ }^{1,2}$, N. H. THUAN²,3, HARITHA POLIMATI, V. B. TATIPAMULA ${ }^{2,3}$, G. V. S. KUMAR AND S. K. RANAJIT ${ }^{4}$

Department of Pharmacology, AU College of Pharmaceutical Sciences, Andhra University, Visakhapatnam-530 003, India, ${ }^{1}$ Department of Medical Microbiology and Parasitology, Faculty of Medicine, Duy Tan University, Da Nang 550000, Vietnam, ${ }^{2}$ Center for Molecular Biology, Duy Tan University, Duy Tan University, Da Nang 550000, Vietnam, ${ }^{3}$ Faculty of Pharmacy, Duy Tan University, Da Nang 550000, Vietnam, ${ }^{4}$ School of Pharmacy, Centurion University of Technology and Management, Odisha 767001, India
\end{abstract}

\section{Killari et al.: Protective Effects of Microdus brasiliensis in Sepsis}

\begin{abstract}
The present study investigated the phytochemical, total flavonoid and total phenolic content, antibacterial activity, acute toxicity studies, hemodynamic parameters, myeloperoxidase activity of ethanolic extract of Microdus brasiliensis and its effects on cecal ligation and puncture induced sepsis in mice. The preliminary phytochemical screening showed that Microdus brasiliensis contains alkaloids, terpenoids, flavonoids, phenolics, saponins and tannins. The Microdus brasiliensis found to contain good amounts of total flavonoid and phenolic content. At equivalent concentration, Microdus brasiliensis showed antibacterial activities as potent as streptomycin against Staphylococcus aureus, Salmonella typhi and Escherichia coli. Acute toxicity studies on mice found out that Microdus brasiliensis was non-toxic up to $2000 \mathrm{mg} / \mathrm{kg}$ body weight. At both low and high doses, Microdus brasiliensis improved hemodynamic parameters such as mean arterial pressure and decreased optical density of blood and serum myeloperoxidase activity. Moreover, at a high dose, Microdus brasiliensis reduced survival rate to $80.34 \pm 3.67 \%$ in mice that might be through pro-inflammatory effects. The results indicate that Microdus brasiliensis can be a favorable natural source for the treatment of cecal ligation and puncture induced sepsis in mice.
\end{abstract}

Key words: Anti-bacterial activity, cecal ligation and puncture induced sepsis, hemodynamics parameters, myeloperoxidase activity, total phenolic content

Sepsis is one of the major causes of death in intensive care units and no decisive medical treatment is available against sepsis. Globally, it is the major cause of death from infection in intensive care units ${ }^{[1]}$. It is a lethal clinical syndrome that results from the dysregulated systemic inflammatory response of the body due to the invasion of pathogens ${ }^{[2]}$. The complications of sepsis are varied and involve coagulation disorders, immune suppression, organ dysfunction and systemic inflammation $^{[3,4]}$.

Severe sepsis affects the cardiovascular system that causes cardiomyopathy and endothelial dysfunction, which results from adverse effects of substances secreted from pathogens and host cells ${ }^{[5]}$. Also, sepsis impairs neutrophil migration and its antimicrobial activity. Inadequate migration of neutrophils into

*Address for correspondence

E-mail: kishorenaidu.killari@gmail.com

May-June 2021 the site of infection causes the systemic spread of pathogens, which results in high rates of mortality. The initial management of infection in sepsis requires initiating appropriate and timely antibiotic therapy ${ }^{[6]}$. However, there is no specific therapy or drug against sepsis. Hence, searching to find a new medication for the management of sepsis is necessary. Many of the available medicines are derived from herbs and medicinal plants have long been used to treat various disorders.

\footnotetext{
This is an open access article distributed under the terms of the Creative Commons Attribution-NonCommercial-ShareAlike 3.0 License, which allows others to remix, tweak, and build upon the work non-commercially, as long as the author is credited and the new creations are licensed under the identical terms
} Indian J Pharm Sci 2021;83(3):437-442 
Microdus genus (Dicranaceae family) is a moss with around 92 species all over the world and well recorded in the flora of Vietnam, India, Thailand, Canada and China $^{[7,8]}$. In traditional medicine, Microdus species has wide applications in the treatment of microbial infections ${ }^{[9]}$. To date, no proper phytochemical and biological investigations have attempted on Microdus brasiliensis $(\mathrm{Mb})$. So, the current investigation mainly aimed to evaluate the phytochemical analysis, total flavonoid content, total phenolic content and antibacterial activity of whole moss $\mathrm{Mb}$ extract and also its protective effects on hemodynamic parameters, myeloperoxidase (MPO) activity as well as survival rate were evaluated in cecal ligation and puncture (CLP) induced sepsis in mice.

\section{MATERIALS AND METHODS}

\section{Collection:}

The whole moss of Microdus brasiliensis (Duby) Thér. was collected from Son Tra Mountains, Danang, Vietnam in 2020 and a voucher specimen (DTU/ DB/2020/Moss/1204) has deposited at Department of Botany, Duy Tan University, Danang, Vietnam.

\section{Extraction:}

The whole moss was dried and powdered (200 g) and extracted three times with ethanol $(96 \%)$ at $25^{\circ}$. All combined and evaporated under low pressure to obtain an ethanolic extract of $\mathrm{Mb}(2.0 \mathrm{~g})$, which was preserved in an amber color bottle at $4^{\circ[10]}$.

\section{Preliminary phytochemical analysis:}

Preliminary phytochemical analysis upon $\mathrm{Mb}$ was performed according to the standard practical methods $^{[11,12]}$.

\section{Assay for total flavonoid Content:}

The total flavonoid content of the $\mathrm{Mb}$ was determined by using aluminum chloride $\left(\mathrm{AlCl}_{3}\right)$ spectrophotometric method $^{[13]}$, in which $\mathrm{AlCl}_{3}$ forms complex with hydroxyl groups of flavonoids that exist in the testing sample. To the $\mathrm{Mb}(1 \mathrm{mg} / \mathrm{ml})$ or standard quercetin solution (3.125, $6.25,12.5,25,50,100 \mu \mathrm{g} / \mathrm{ml}$ ) added $3 \mathrm{ml}$ of methanol, $1 \mathrm{ml}$ of $2 \% \mathrm{AlCl}_{3}$ solution, $200 \mu \mathrm{l}$ of $1 \mathrm{M}$ potassium acetate and made up to $10 \mathrm{ml}$ with distilled water and incubated for $60 \mathrm{~min}$ at room temperature. In contrast, the blank contains only reagents and the absorbance was noted at $415 \mathrm{~nm}$. Based on the measured absorbance of the test sample, the total flavonoid content was read on the calibration line and the total flavonoid content was expressed in terms of quercetin equivalent ( $\mathrm{mg}$ of quercetin/g of extract).

\section{Assay for total phenolic content:}

The total phenolic content of $\mathrm{Mb}$ was established through the Folin-Ciocalteu reagent ${ }^{[14]}$. Initially, five hundred microliters of $\mathrm{Mb}$ were mixed with $5 \mathrm{ml}$ of Folin-Ciocalteu reagent $10 \%(\mathrm{v} / \mathrm{v})$ in distilled water, diluted and $4 \mathrm{ml}$ of sodium bicarbonate solution (1 M) was added. After $15 \mathrm{~min}$ of incubation time for the mixture at room temperature, the absorbance of the produced blue color was read by spectrophotometer. Ultimately, the total phenolic content of $\mathrm{Mb}$ was calculated from the calibration curve of gallic acid and expressed as gallic acid equivalent, respectively ${ }^{[15]}$.

\section{Antibacterial activity:}

In vitro antimicrobial activity of $\mathrm{Mb}$ was performed by the cup-plate method ${ }^{[16]}$. The test bacteria used in this study were two gram-positive bacteria: Staphylococcus aureus (ATCC25923) and Bacillus subtilis (ATCC21332) and two gram-negative bacteria: Salmonella typhi (ATCC1408) and Escherichia coli (ATCC25922). Mueller Hinton agar plates inoculated with $0.5 \mathrm{McF}$ arland standards of mentioned bacteria were used for this assessment. Test strains were inoculated by spread plate technique and wells were made by sterile cork borer. Accurately $50 \mu 1$ (100 $\mu \mathrm{g} / \mathrm{ml}$ concentration) of $\mathrm{Mb}$ and standard, streptomycin was poured in each well. After $24 \mathrm{~h}$ incubation at $37^{\circ}$, inhibition zones were measured by a calibrated scale ${ }^{[17]}$.

\section{Animals:}

Adult male mice (weighting $25 \pm 5 \mathrm{mg}$, age $6-8 \mathrm{w}$ ) were used in this study. The animals were given food and water ad libitum and were housed in the animal house of Duy Tan University of Medicine and Pharmacy under the standard condition with a temperature of $21 \pm 2^{\circ}$, the relative humidity of $50 \pm 10 \%$ and a $12 \mathrm{~h}$ light $/ 12 \mathrm{~h}$ dark cycle ${ }^{[18]}$. This study was approved by the Ethics Committee of Duy Tan University of Medicine and Pharmacy (Code: VN.DTU.MP.2020.442).

\section{Acute oral toxicity:}

Mice were randomly divided into 4 groups (6 mice in each group). The organisation for economic cooperation and development (OECD) main test 425 (up and down dose procedure) was utilized using doses of 
$175,550,1750$ and $2000 \mathrm{mg} / \mathrm{kg}$ body weight (b.w) of $\mathrm{Mb}$. The test animals have undergone fasting overnight before administering the extract using oral gavage. The first set of test animals was administered with a dose of $175 \mathrm{mg} / \mathrm{kg}$ b.w. When the animal survived after $48 \mathrm{~h}$, the dose that was given to the next sets of rodents was increased by a factor 3.2, which was $550 \mathrm{mg} / \mathrm{kg}$ b.w. After $48 \mathrm{~h}$ of survival, the next test animal was given $1750 \mathrm{mg} / \mathrm{kg}$ b.w then the same cycle is repeated and the upper bound dose of $2000 \mathrm{mg} / \mathrm{kg}$ b.w was given to the test rodents. The testing was ended until the last three animals survived the upper bound dose and all of the test animals were observed up to $14 \mathrm{~d}^{[19,20]}$.

\section{CLP-induced sepsis in mice:}

CLP-induced model ${ }^{[21]}$ was used for the induction of sepsis. At the beginning of the experiment, mice were randomly divided into 4 groups (6 mice in each group). Mice in group 1 (normal control), underwent midline abdominal incision without CLP. Mice in group 2 (CLP-induced), underwent midline abdominal incision with cecal ligation $(50 \%)$ and punctured to induce polymicrobial sepsis. Mice in groups 3 and 4 received $100 \mathrm{mg} / \mathrm{kg}$ b.w (as a low dose) and $200 \mathrm{mg} / \mathrm{kg}$ b.w (as a high dose) of $\mathrm{Mb}$ intraperitoneal (i.p) at 0, 1, 3, 6 and $24 \mathrm{~h}$ after CLP-induced operation. Blood samples were obtained from the portal vein. $0.5 \mathrm{ml}$ of blood samples were transferred into laboratory tubes containing preautoclaved nutrient broth medium (Sigma-Aldrich, Germany) and put in an incubator at $37^{\circ}$. The remaining blood samples were decanted gently into collection plastic tubes and then centrifuged at $3000 \mathrm{rpm}$ for $5 \mathrm{~min}$. Then serum was obtained, aliquoted into microtubes and stored at $-20^{\circ}$ for biochemical analysis.

Later, mice were anesthetized by i.p injection of ketamine (60 mg/kg b.w) and xylazine (10 mg/kg b.w). Then, the abdominal region of animals was shaved and sterilized by betadine. The cecum was exposed through a midline abdominal incision and ligated (50\%) with $3 / 0$ silk suture then punctured with a sterile 18 gauge needle. The cecum was gently squeezed and after a drop of cecal contents was discharged, the cecum was repositioned into the abdominal cavity. The abdominal wall and skin were closed with $3 / 0$ silk suture. After the surgery, mice received $3 \mathrm{ml}$ warm $0.9 \%$ normal saline subcutaneously (s.c) for fluid resuscitation. After mice recovered from anesthesia, they had free access to food and water.

\section{Animal survival rate:}

In addition to monitoring the animals for $3 \mathrm{~d}$, animals survival rate was reported after $72 \mathrm{~h}^{[22]}$.

\section{Hemodynamic parameters:}

For measurements of hemodynamic parameters such as arterial blood pressure, mean arterial blood pressure, developed pressure and heart rate, a polyethylene cannula connected to a pressure transducer that prefilled with heparinized normal saline solution was cannulated into the right common carotid artery ${ }^{[22]}$.

\section{MPO measurement:}

The activity of $\mathrm{MPO}^{[23]}$ was assessed as previously described with minor modifications. Briefly, $1 \mathrm{ml}$ of the serum was mixed with $1 \mathrm{mg}$ of hexadecyltrimethylammonium bromide (HTAB). Then sonicated for $5 \mathrm{~min}$ and centrifuged at $3000 \mathrm{rpm}$ for $10 \mathrm{~min}$ at $4^{\circ} .0 .1 \mathrm{ml}$ of supernatant was mixed with $2.9 \mathrm{ml}$ of $50 \mathrm{mM}$ phosphate buffer (pH 6.0), containing $0.167 \mathrm{mg} / \mathrm{ml} \mathrm{O}$-Dianisidine dihydrochloride and $1 \%$ hydrogen peroxide. Then the mixture was incubated for $5 \mathrm{~min}$ at room temperature. After adding $0.1 \mathrm{ml}$ of 1.2 M hydrogen chloride ( $\mathrm{HCl}$ ) the change in absorbance was measured at $460 \mathrm{~nm}$ using a spectrophotometer.

\section{RESULTS AND DISCUSSION}

Phytochemical analysis, results of the preliminary phytochemical screening of $\mathrm{Mb}$ possesses alkaloids, terpenoids, flavonoids, phenolics, saponins and tannins, among the tested class of compounds. Besides, coumarins, phenanthrenes, anthraquinones, bibenzyls, fluorenones and cardiac glycosides were found to be absent in the extract.

Additionally, total flavonoid content and total phenolic content was ascertained via the absorbance of $\mathrm{Mb}$ and the equation obtained from the standard curve of quercetin and gallic acid, respectively. As a consequence, the total flavonoid content and total phenolic value for $\mathrm{Mb}$ were equivalent to $122.40 \pm 4.38 \mathrm{mg}$ of quercetin per $1 \mathrm{~g}$ of dried plant material and $211.6 \pm 7.8 \mathrm{mg}$ of gallic acid per $1 \mathrm{~g}$ of dried plant material, respectively.

Acute oral toxicity (OECD main test 425) shows that $\mathrm{Mb}$ was non-toxic up to $2000 \mathrm{mg} / \mathrm{kg}$ b.w of tested mice. There were no significant changes that occurred in the pattern of behavior of the tested animals. No mortality was noted for $14 \mathrm{~d}$. These results present that the extract is non-toxic up to $2000 \mathrm{mg} / \mathrm{kg}$ b.w and the low $\left(1 / 20^{\text {th }}\right)$ 
and high $\left(1 / 10^{\text {th }}\right)$ dosage was fixed as 100 and $200 \mathrm{mg} /$ $\mathrm{kg}$ b.w, respectively.

The results of in vitro antimicrobial activity of $\mathrm{Mb}$ revealed that it has antibacterial activity against both gram-positive bacteria ( $S$. aureus and $B$. subtilis) and gram-negative bacteria (S. typhi and E. coli). As can be seen in Table 1, Mb was as potent as standard streptomycin against $S$. aureus, $S$. typhi and E. coli and showed the same zone of inhibitory effect, while on B. subtilis has a significant zone of inhibition, compared to streptomycin.

Optical density (OD) of blood at $600 \mathrm{~nm}$ is shown in fig. 1 where the OD of blood significantly $(p<0.01)$ increased in the CLP-induced group compared with the normal control group. On the other hand, the administration of $\mathrm{Mb}$ (at both doses) to the septic mice significantly $(p<0.05)$ decreased OD in the blood of animals compared with the CLP-induced group.

Hemodynamic responses were seen and it was observed that the mean arterial pressure was significantly decreased from $113.84 \pm 6.17 \mathrm{~mm}$ of $\mathrm{Hg}$ in the normal control group to $57.0 \pm 3.0 \mathrm{~mm}$ of $\mathrm{Hg}(-49.93 \%)$ in the CLP-induced group $(\mathrm{p}<0.05)$. There was a significant decrease $(p<0.05)$ in the mean arterial pressure of mice treated with $\mathrm{Mb}$ at 100 and $200 \mathrm{mg} / \mathrm{kg}$ b.w to $81.67 \pm 2.34(-28.26 \%)$ and $102.5 \pm 5.5(-9.96 \%) \mathrm{mm}$ of $\mathrm{Hg}$, respectively, compared to control and CLPinduced group. It was found that arterial blood pressure from $142.0 \pm 8.0 \mathrm{~mm}$ of $\mathrm{Hg}$ in the normal control group decreased to $44.13 \%(79.34 \pm 4.67 \mathrm{~mm}$ of $\mathrm{Hg}, \mathrm{p}<0.001)$ in the CLP-induced group.

TABLE 1: ANTIBACTERIAL SCREENING TEST OF ETHANOLIC EXTRACT OF Microdus brasiliensis (Mb)

\begin{tabular}{lcccc}
\hline & \multicolumn{3}{c}{ Zone of inhibition $(\mathrm{mm})^{*}$} \\
\cline { 2 - 5 } Sample & \multicolumn{2}{c}{ Gram-positive } & \multicolumn{2}{c}{ Gram-negative } \\
\cline { 2 - 5 } & B. subtilis & S. aureus & E. coli & S. typhi \\
Mb & $25.0 \pm 0.2$ & $23.7 \pm 0.1$ & $18.2 \pm 0.1$ & $22.0 \pm 0.1$ \\
Streptomycin & $28.7 \pm 0.1$ & $24.1 \pm 0.1$ & $19.5 \pm 0.1$ & $22.2 \pm 0.1$ \\
\hline *Mean $\$$ SD values $(\mathrm{n}=3)$ & &
\end{tabular}

Treatment with $\mathrm{Mb}$ at 100 and $200 \mathrm{mg} / \mathrm{kg}$ b.w increased the arterial blood pressure $(\mathrm{p}<0.001)$ significantly with $9.98 \%(220.34 \pm 7.67 \mathrm{~mm}$ of $\mathrm{Hg})$ and $2.08 \%$ (204.50 $\pm 55 \mathrm{~mm}$ of $\mathrm{Hg}$ ), compared to CLP-induced group. Similarly, the heart rate increased insignificantly in the CLP-induced group (28.03\%), compared to the control group. Treatment with $\mathrm{Mb}$ at 100 and $200 \mathrm{mg} / \mathrm{kg}$ b.w almost showed a similar heart rate as that of the normal control group (Table 2). Developed pressure insignificantly decreased in the CLP-induced

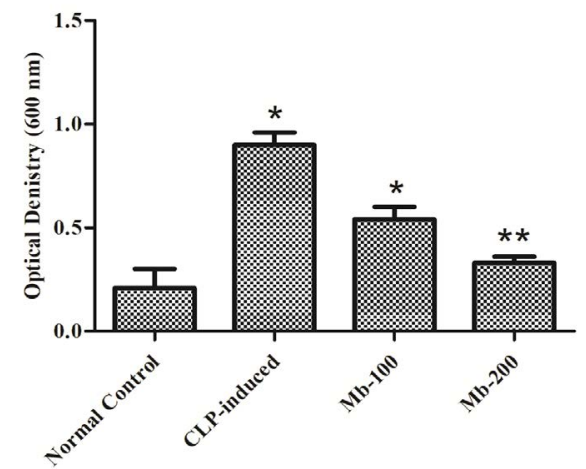

Fig. 1: Effect of ethanolic extract of $\mathrm{Mb}$ on $\mathrm{OD}$ at $600 \mathrm{~nm}$ Values are mean \pm standard deviation (SD) $(n=6) ; * p<0.05$, as compared with the normal control group; **p<0.01, as compared with CLP-induced group using one-way analysis of variance (ANOVA) with Student-Newman-Keuls post hoc test; Mb-100: Mb at $100 \mathrm{mg} / \mathrm{kg} \mathrm{b.w;} \mathrm{Mb-200:} \mathrm{Mb} \mathrm{at} 200 \mathrm{mg} / \mathrm{kg}$ b.w

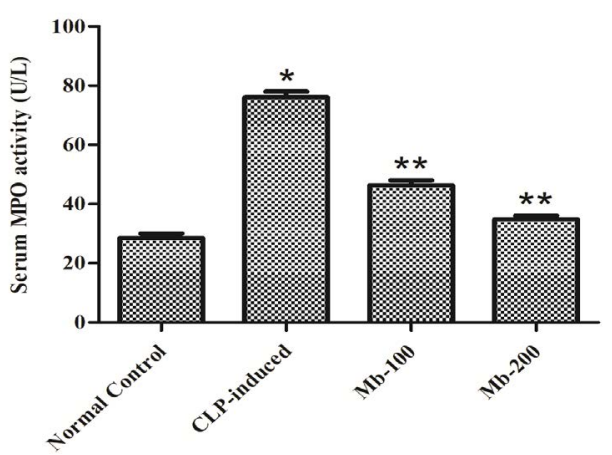

Fig. 2: Effect of ethanolic extract of Mb on MPO activity Values are mean $\pm S D(n=6) ; *<<0.05$, as compared with the normal control group; **p<0.01, as compared with CLPinduced group using one-way ANOVA with Student-NewmanKeuls post hoc test. Mb-100: Mb at $100 \mathrm{mg} / \mathrm{kg} \mathrm{b.w;} \mathrm{Mb-200:}$ $\mathrm{Mb}$ at $200 \mathrm{mg} / \mathrm{kg} \mathrm{b.w}$

TABLE 2: EFFECTS OF ETHANOLIC EXTRACT OF Microdus brasiliensis ON HEMODYNAMIC PARAMETERS IN CLP-INDUCED SEPSIS AFTER $72 \mathrm{~h}$

\begin{tabular}{lcccc}
\hline \multirow{2}{*}{ Sample } & \multicolumn{4}{c}{ Hemodynamic parameters $(\mathrm{mm} \text { of } \mathrm{Hg})^{*}$} \\
\cline { 2 - 5 } & Mean arterial pressure & Arterial blood pressure & Heart rate & Developed pressure \\
\hline Normal Control & $113.84 \pm 6.17$ & $142.0 \pm 8.0$ & $200.34 \pm 9.67$ & $38.34 \pm 3.67$ \\
CLP & $57.0 \pm 3.0^{\mathrm{a}}(-49.93 \%)$ & $79.34 \pm 4.67^{\mathrm{b}}(-44.13 \%)$ & $256.5 \pm 13.5(+28.03 \%)$ & $21.5 \pm 2.5^{\mathrm{a}}(-43.92 \%)$ \\
Mb-100 & $81.67 \pm 2.3^{\mathrm{c}}(-28.26 \%)$ & $111.17 \pm 8.84^{\mathrm{d}}(-21.71 \%)$ & $220.34 \pm 7.67(+9.98 \%)$ & $27.0 \pm 3.0(-29.58 \%)$ \\
Mb-200 & $102.5 \pm 5.5^{\mathrm{d}}(-9.96 \%)$ & $126.5 \pm 5.5^{\mathrm{c}}(-10.92 \%)$ & $204.50 \pm 5.5(+2.08 \%)$ & $32.17 \pm 3.84(-16.09 \%)$ \\
\hline
\end{tabular}

${ }^{*}$ Mean \pm SD values $(n=6)$; one-way ANOVA with Student-Newman-Keuls post hoc test was used for wise pair comparison where ${ }^{a} \mathrm{p}<0.05$, ${ }^{\mathrm{b}} \mathrm{p}<0.001$ vs. normal control group; ${ }^{c} p<0.05$, ${ }^{d} p<0.001$ compared with CLP group. Mb-100: Mb at $100 \mathrm{mg} / \mathrm{kg} \mathrm{b.w;} \mathrm{Mb-200:} \mathrm{Mb} \mathrm{at} 200 \mathrm{mg} / \mathrm{kg}$ b.w 
group (43.92\%) and $\mathrm{Mb}$ treated at 100 and $200 \mathrm{mg} / \mathrm{kg}$ b.w (29.58 and $16.09 \%$, respectively), compared to the control group (Table 2).

Serum MPO activity of animals in the CLP-induced group showed a significant $(\mathrm{p}<0.05)$ increase in MPO activity compared with the normal control group. The treatment of mice with $\mathrm{Mb}$ (at both doses) decreased markedly $(\mathrm{p}<0.01)$ the enzyme activity compared with the CLP-induced group (fig. 2).

To examine the effects of $\mathrm{Mb}$ on survival rates, the animals were monitored for $72 \mathrm{~h}$ after CLP-induced surgery. There was no death of mice in the normal control group after $72 \mathrm{~h}$ and the survival rate was $100.0 \pm 0.0 \%$. At $72 \mathrm{~h}$, the survival rate decreased in the CLP-induced group to $33.67 \pm 2.34 \%$ compared with the normal control group. Treatment of septic mice with $\mathrm{Mb}$ with doses of 100 and $200 \mathrm{mg} / \mathrm{kg}$ b.w decreased survival rate to $60.84 \pm 5.17 \%$ and $80.34 \pm 3.67 \%$, respectively, at $72 \mathrm{~h}$ (fig. 3).

In the present study, we showed that $\mathrm{Mb}$ improved hemodynamic parameters with potent antibacterial activity. In addition, $\mathrm{Mb}$ unexpectedly decreased the inflammatory response and mortality rate in mice with polymicrobial sepsis. Besides, preliminary phytochemical screening showed that $\mathrm{Mb}$ contains alkaloids, terpenoids, flavonoids, phenolics and tannins. Also, a good amount of total phenolic content was observed in $\mathrm{Mb}$.

Our results showed that $\mathrm{Mb}$ has antibacterial activity against E. coli and $S$. aureus (Table 1). As these bacteria are the predominant cause of sepsis, this edible flower can have beneficial effects against sepsis ${ }^{[24]}$. The antibacterial activity of $\mathrm{Mb}$ might be related to its phytochemical contents because several studies have reported the antibacterial activities of alkaloids, flavonoids and phenolic acids ${ }^{[2-6]}$.

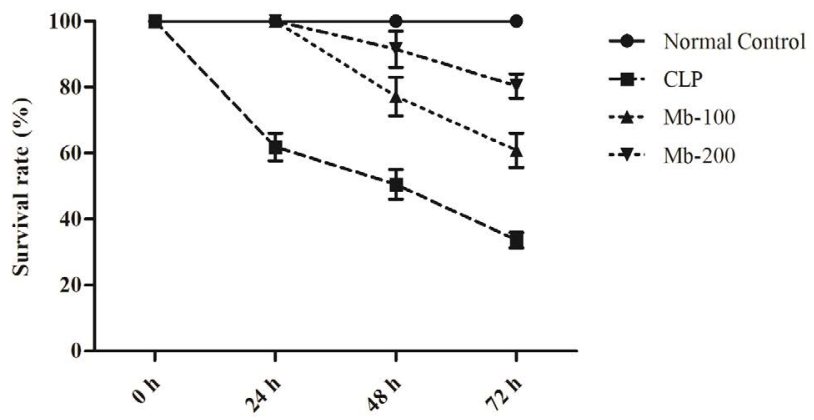

Fig. 3: Effect of ethanolic extract of $\mathrm{Mb}$ on survival rate after 72 h $(n=6)$

Values are mean $\pm \mathrm{SD}(\mathrm{n}=6)$; $\mathrm{Mb}-100: \mathrm{Mb}$ at $100 \mathrm{mg} / \mathrm{kg}$ b.w; Mb200: $\mathrm{Mb}$ at $200 \mathrm{mg} / \mathrm{kg} \mathrm{b.w}$

May-June 2021
As mentioned, sepsis causes cardiac and endothelial dysfunction ${ }^{[5,25]}$. The hemodynamic monitoring in this study showed attenuation of hemodynamic parameters in the CLP-induced group. This event can lead to misbalancing in tissues oxygen supply/demand and accelerates the process of septic shock. For this reason, apart from antibiotic therapy, hemodynamic stability is essential in the management of sepsis ${ }^{[6]}$. Administration of $\mathrm{Mb}$ (at both doses) to the septic mice significantly $(p<0.05)$ decreased OD in the blood of animals compared with the CLP-induced group (fig. 1). Administration of $\mathrm{Mb}$ to septic mice increased mean arterial and blood pressure, compared to CLP-induced group (Table 2). Therefore, the administration of medications extracted from $\mathrm{Mb}$ might be useful for the treatment of sepsis.

MPO, the major enzyme in azurophilic granules of neutrophils, is a marker of inflammation initiation in plasma. Thus, increased MPO activity indicates the onset of the inflammatory response and neutrophil infiltration due to the induction of microbial sepsis ${ }^{[23]}$. Our results showed that MPO activity increased in the serum of animals with CLP-induced poly-microbial sepsis in comparison to normal animals. Administration of Mb decreased MPO activity, which shows the control of the pro-inflammatory effect of $\mathrm{Mb}$ when compared to CLP-induced group (fig. 2). Evidence related to the pro-inflammatory activities of $\mathrm{Mb}$ is poor. Also, the present study demonstrated a reduction in survival rate in CLP-induced sepsis in mice (fig. 3). The reason for high mortality rates in sepsis is the excessive release of cytokines, which results in a hyper inflammatory state.

To conclude, the result of the present study is the first report of moss $\mathrm{Mb}$, as a double edge sword in the treatment of CLP-induced sepsis in mice. The key phytochemicals responsible for this activity claimed to be alkaloids, flavonoids, polyphenols, saponins and tannins. The results provide evidence that supports the traditional uses of $\mathrm{Mb}$. Also, these findings suggest that moss $\mathrm{Mb}$ can take an account as a good natural source of remedial medicine for sepsis. Hence, the results of the current study remain useful for further research to identify the potential bioactive molecules from $\mathrm{Mb}$.

\section{Acknowledgments:}

None to acknowledge.

\section{Conflicts of Interest:}

The authors declared no conflict of interest.

\section{REFERENCES}

1. Cohen J. The immunopathogenesis of sepsis. Nature 
2002;420:885-91.

2. Chirico G, Cortinovis S, Fonte C, Giudici G. Bacterial sepsis. J Chemother 2007;19:28-30.

3. Wittebole X, De Roock S, Opal SM. A historical overview of bacteriophage therapy as an alternative to antibiotics for the treatment of bacterial pathogens. Virulence 2014;5(1):226-35.

4. Ramachandran G. Gram-positive and gram-negative bacterial toxins in sepsis: a brief review. Virulence 2014;5(1):213-8.

5. Fink MP. Animal models of sepsis and its complications. Kidney Int 2008;74(8):991-3.

6. Wheeler AP, Bernard GR. Treating patients with severe sepsis. N Engl J Med 1999;340(3):207-14.

7. Richardson CH. A new braconid of the genus Microdus from Canada. Can Entomol 1913;45(7):211-2.

8. Chopra RN, Mehta P. Effect of some known growth regulators on growth and fertility in male clones of the moss Microdus brasiliensis (Dub.) Ther. J Exp Bot 1987;38(2):331-9.

9. Asakawa Y. Biologically active substances from bryophytes. In Bryophyte development: Physiology and biochemistry. CRC Press; 2019. p. 259-88.

10. Tatipamula VB, Killari KN, Prasad K, Rao GS, Talluri MR, Vantaku S, et al. Cytotoxicity studies of the chemical constituents from marine algae Chara baltica. Indian J Pharm Sci 2019;81(5):815-23.

11. Talluri MR, Ketha A, Battu GR, Tadi RS, Tatipamula VB. Protective effect of Aurelia aurita against free radicals and streptozotocin-induced diabetes. Bangladesh J Pharmacol 2018;13(3):287-95.

12. Tatipamula VB, Killari KN, Ketha A, Sastry VG. Taxithelium napalense acts against free radicals and diabetes mellitus. Bangladesh J Pharmacol 2017;12(2):197-203.

13. Tatipamula VB, Vedula GS, Rathod BB, Shetty PR, Sastry AV. Study of phytochemical analysis, total flavonoid and phenolic content, antimicrobial properties and chemical constituents of two manglicolous lichens extracts. Inven Rapid Planta Act 2018;2018(2):1-6.

14. Tatipamula VB, Killari KN, Gopaiah KV, Ketha A. GCMS Analysis of Ethanol Extract of Taxithelium napalense
(Schwaerg) Broth along with its alpha-Glucosidase Inhibitory Activity. Indian J Pharm Sci 2019;81(3):569-74.

15. Tatipamula VB, Kukavica B. Protective effects of extracts of lichen Dirinaria consimilis (Stirton) DD Awasthi in bifenthrinand diazinon-induced oxidative stress in rat erythrocytes in vitro. Drug Chem Toxicol 2020:1-8.

16. Sastry AV, Vedula GS, Tatipamula VB. In vitro biological profile of mangrove associated lichen, Roccella montagnei extracts. Inven Rapid Ethnopharmacol 2018;2018(3):153-8.

17. Tatipamula VB, Vedula GS. Antimicrobial and anti-tubercular activities of isolates and semi synthetic derivatives of lichen Ramalina leiodea (Nyl.) Nyl. J Serbian Chem Soc 2019;84(6):555-62.

18. Paidi KR, Tatipamula VB, Kolli MK, Annam SS, Pedakotla VR. Synthesis of imidazo [1, 2-b] pyridazine comprised piperazine, morpholine derivatives as potent antimycobacterial agents with in vivo locomotor activity. Antiinfect Agents 2017;15(2):131-9.

19. Tatipamula VB, Kolli MK, Lagu SB, Paidi KR, Reddy R, Yejella RP. Novel indolizine derivatives lowers blood glucose levels in Streptozotocin-induced diabetic rats: A histopathological approach. Pharmacol Rep 2019;71(2):233-42.

20. Tatipamula VB, Annam SS, Nguyen HT, Polimati H, Yejella RP. Sekikaic acid modulates pancreatic $\beta$-cells in streptozotocininduced type 2 diabetic rats by inhibiting digestive enzymes. Nat Prod Res 2020:1-5.

21. Rittirsch D, Huber-Lang MS, Flierl MA, Ward PA. Immunodesign of experimental sepsis by cecal ligation and puncture. Nat Protoc 2009;4(1):31-6.

22. Bolton CF, Young GB. Zochodne W. The neurological complications of sepsis. Ann Neurol 1993;33:94-100.

23. Ward PA. New approaches to the study of sepsis. EMBO Mol Med 2012;4(12):1234-43.

24. Church D, Elsayed S, Reid O, Winston B, Lindsay R. Burn wound infections. Clin Microbiol Rev 2006;19(2):403-34.

25. Hotchkiss RS, Monneret G, Payen D. Sepsis-induced immunosuppression: from cellular dysfunctions to immunotherapy. Nat Rev Immunol 2013;13(12):862-74. 